\title{
Enhanced hypocrellin production via coexpression of alpha-amylase and hemoglobin genes in Shiraia bambusicola
}

\author{
Ruijie Gao@, Huaxiang Deng, Zhengbing Guan, Xiangru Liao and Yujie Cai ${ }^{*}$
}

\begin{abstract}
Shiraia bambusicola is an important and valuable macrofungus and hypocrellins are its main secondary metabolites which have been widely applied in many medical fields. However, during SSF process of this filamentous fungus, use ratio of corn substrate and dissolved oxygen supply are two main limiting factors, which influence production cost, yield and product quality. To solve these problems, overexpressions of amy365-1 and vgb in S. bambusicola were investigated and three overexpression transformants were constructed. Results demonstrated that expressions and coexpression of AMY365-1 and VHb not only increased the productions of biomass, amylase, hypocrellin, but also up-regulated relative expression levels of four central carbon metabolism genes ( $p d c$, ald, acs, acc) and seven hypocrellin biosynthesis genes (fad, mono, zftf, omef, msf, pks, mco). Furthermore, expression of VHb decreased SSF period. When amy365-1 and $v g b$ were coexpressed, relative expression levels of $\mathrm{ztf}$ and $p k s$ reached their highest levels at $72 \mathrm{~h}$ under liquid fermentation, hypocrellin production reached the highest level $75.85 \mathrm{mg} / \mathrm{gds}$ which was 2.99 -fold compared with wild type strain within 11 days under SSF, and residual starch of solid substrates was decreased from 35.47 to $14.57 \%$.
\end{abstract}

Keywords: Hypocrellin, Coexpression, Amylase, Hemoglobin, Solid state fermentation, Shiraia sp. SUPER-H168

\section{Introduction}

Shiraia bambusicola is an important and valuable macrofungus in the medical and food industries. Hypocrellins are the main secondary metabolites of $S$. bambusicola, including hypocrellin $\mathrm{A}$, hypocrellin $\mathrm{B}$, hypocrellin $\mathrm{C}$ and hypocrellin D (Fang et al. 2006), a type of perylenequinone. Under illumination, hypocrellins react with oxygen and generate reactive oxygen species (ROS), including singlet oxygen $\left({ }^{1} \mathrm{O}_{2}\right)$ and the superoxide radical. Abundant ROS cause cellular oxidative stress and kill cells by damaging cellular macromolecules, including lipids, DNA and proteins (Trachootham et al. 2008). Based on this characteristic, hypocrellins have been widely applied in many medical fields, such as photodynamic tumor therapy and antivirus treatments (Gao et al. 2012; Jin et al. 2013). They also have been used to treat skin

\footnotetext{
*Correspondence: yjcai@jiangnan.edu.cn

Key Laboratory of Industrial Biotechnology, School of Biotechnology,

Jiangnan University, 1800 Lihu Road, Wuxi 214122, Jiangsu, China
}

diseases, gastric diseases and some vascular diseases. In addition to benefiting the pharmaceutical industry, hypocrellins also have extensive potential applications in the agricultural, cosmetic, food, and feed industries (Shen et al. 2012; Su et al. 2010, 2011). So far, yield of hypocrellin from natural extraction was too low to meet it current medical demand. Therefore, improvement of hypocrellin production was needed to meet its demand.

In our previous work, we isolated a high-yield hypocrellin producing strain, Shiraia sp. SUPER-H168 (Liang et al. 2009); hypocrellins produced by Shiraia sp. SUPERH168 under solid state fermentation (SSF) have been isolated and identified. At the same time, corn was found to be the best substrate after evaluating eight kinds of agroindustrial crops and residues (Cai et al. 2010). Compared with liquid state fermentation, SSF offers numerous advantages which include high volumetric productivity and relatively higher concentration of the products. SSF was found to be the best fermentation of industrialized production for hypocrellin with S. bambusicola. Cracked 
corn was produced from maize endosperm of which starch is the major constituent. Normal corn starch consists of about $75 \%$ branched amylopectin and about $25 \%$ amylose, that is linear or slightly branched (Sandhu and Singh 2007). In previous studies, residual starch of dry fermented substrate remained at a high level, and hypocrellin production was increased when external amylases were added (data was not showed in this study). In order to improve the yield of hypocrellin and increase the use ratio of corn substrate, an $\alpha$-amylase gene amy3651 (GenBank accession no. MF535183) from Shiraia sp. SUPER-H168 was overexpressed.

Furthermore, during SSF process of the filamentous fungus, the dissolved oxygen supply is a limiting factor, which influences growth, yield, protein production, product quality and production cost (Mora-Lugo et al. 2015; te Biesebeke et al. 2006). Vitreoscilla hemoglobin (VHb) is a soluble homodimeric protein, which is synthesized by aerobic Gram-negative bacterium Vitreoscilla (Wakabayashi et al. 1986) and functions as an oxygen carrier and transporter (Bonaventura et al. 2013). VHb expression in heterologous hosts can improve oxidative metabolism, cell growth, protein synthesis, bioremediation and metabolite production (Heerd et al. 2012; Hofmann et al. 2009; Li et al. 2016a, b; Mora-Lugo et al. 2015; Stark et al. 2011, 2015; Zhang et al. 2014; Zhu et al. 2011). To the best of our knowledge, $\mathrm{VHb}$ has not been used in $S$. bambusicola to date. Therefore, the $v g b$ gene engineering in Shiraia sp. SUPER-H168 was explored and the effects of $\mathrm{VHb}$ on growth and hypocrellin production were investigated.

In this study, overexpressions of amy365-1 and $v g b$ in $S$. bambusicola were investigated, respectively. Furthermore, coexpression of amy365-1 and $v g b$ was also investigated. Related genes of hypocrellin biosynthesis and enzymes in central carbon metabolism for efficient conversion of sugars into acetyl-CoA were investigated. Related genes of hypocrellin biosynthesis included FAD/ FMN-containing dehydrogenase gene $(f a d)$, salicylate 1-monooxygenase gene (mono), zinc finger transcription factor gene (zftf), $O$-methyltransferase gene (omef), major facilitator superfamily gene (msf), polyketide synthase gene $(p k s)$, multicopper oxidase gene (mco) which were reported by Deng et al. (2016a). Hypocrellin which is a polyketide is synthesized from one molecule of acetyl-CoA and six molecules of malonyl-CoA (Deng et al. 2016a; Newman and Townsend 2016). Four genes of enzymes in central carbon metabolism which convert pyruvate to acetyl-CoA and malonyl-CoA were also investigated. They are pyruvate decarboxylase gene $(p d c)$, acetaldehyde dehydrogenase gene (ald) and acetyl-CoA synthetase gene (acs) and acetyl-CoA carboxylase gene $(a c c)$.

\section{Materials and methods \\ Materials}

Corn was purchased from local supermarket (self-brand, Wuxi, Jiangsu, China).

\section{Microorganism and medium}

Shiraia sp. SUPER-H168 (CCTCC M 207104) was a stock culture of the Laboratory of Biochemistry, School of Biotechnology, Jiangnan University, Wuxi, Jiangsu Province, China (Liang et al. 2009). Shiraia sp. SUPER-H168 was routinely maintained on PDA slants at $4{ }^{\circ} \mathrm{C}$ by regular sub-cultivation (no longer than 3 months). Escherichia coli strain DH5 $\alpha$ (Takara, Dalian, China) was used as a host for cloning, and was grown in Luria-Bertani medium at $37^{\circ} \mathrm{C}$.

Regeneration medium: $20 \mathrm{~g} / \mathrm{L}$ glucose, $1 \mathrm{~g} / \mathrm{L} \mathrm{K}_{2} \mathrm{HPO}_{4}$, $0.5 \mathrm{~g} / \mathrm{L} \mathrm{MgSO}_{4} \cdot 7 \mathrm{H}_{2} \mathrm{O}, 0.5 \mathrm{~g} / \mathrm{L} \mathrm{KCl}, 0.01 \mathrm{FeSO}_{4} \cdot 7 \mathrm{H}_{2} \mathrm{O}$, $3 \mathrm{~g} / \mathrm{L}$ yeast extract, $10 \mathrm{~g} / \mathrm{L}$ peptone, $200 \mathrm{~g} / \mathrm{L}$ potato extract, and $0.06 \%$ TritonX-100.

Seed culture medium $(50 \mathrm{~mL})$ which was potato dextrose medium (Liang et al. 2009) was carried out in a Erlenmeyer flask $(250 \mathrm{~mL})$.

Liquid fermented medium was as follows: $5 \%$ corn flour, $1 \%$ yeast extract, $228 \mathrm{mg} / \mathrm{L} \mathrm{K}_{2} \mathrm{HPO}_{4}, 174 \mathrm{mg} / \mathrm{L}$ $\mathrm{K}_{2} \mathrm{SO}_{4}, 294 \mathrm{mg} / \mathrm{L} \mathrm{CaCl}, 492 \mathrm{mg} / \mathrm{L} \mathrm{MgSO}_{4} \cdot 7 \mathrm{H}_{2} \mathrm{O}$, $0.1 \mathrm{mg} / \mathrm{L} \mathrm{ZnSO}_{4}, 0.08 \mathrm{mg} / \mathrm{L} \mathrm{CuSO}_{4}$ and $0.06 \%$ Tween 80 .

Solid-state medium was carried out in a Erlenmeyer flask $(250 \mathrm{~mL})$ with $40 \mathrm{~g}$ cracked corn, and then moistened with salt solution which included glucose $(1.65 \%$, w/w, g/g dry substrate) and $\mathrm{NaNO}_{3}(0.43 \%$, w/w) until $50 \%$ initial moisture contents.

\section{Inoculum preparation}

A spore suspension was obtained as follows: Shiraia sp. SUPER-H168 was grown on PDA slants in dark at $30{ }^{\circ} \mathrm{C}$ for 7 days. The black massive spores were harvested from the surface by pouring sterile distilled water and scraping the spores and homogenized aseptically in a Sorvall Ominimixer for $10 \mathrm{~min}$. The spore concentration was measured by counting with a hemacytometer under microscope (Shi et al. 2009). The spore suspension was used to inoculate the subsequent fermentation immediately. Seed culture was inoculated with $3.5 \mathrm{~mL}$ spore suspension $\left(10^{6}\right.$ spores $\left.\mathrm{mL}^{-1}\right)$ (Cai et al. 2010) and cultured on a rotary shaker at $200 \mathrm{rpm}$ and $30^{\circ} \mathrm{C}$ for $48 \mathrm{~h}$.

\section{Liquid state fermentation}

Liquid culture $(50 \mathrm{~mL})$ in a Erlenmeyer flask $(250 \mathrm{~mL})$ was inoculated with $3.5 \mathrm{~mL}$ seed culture and cultured on a rotary shaker at $200 \mathrm{rpm}$ and $30{ }^{\circ} \mathrm{C}$ for $96 \mathrm{~h}$. Wild type Shiraia sp. SUPER-H168 was chosen as the control strain for analysis of biomass, hypocrellin production, residual sugar and relative expression levels. Hypocrellin was 
produced, extracted and detected as described by Cai et al. (2011). RNA was isolated from different strains at 48,72 and $96 \mathrm{~h}$.

\section{Solid state fermentation}

Fermentation was done at $30{ }^{\circ} \mathrm{C}$ for 15 days under relative humidity higher than $95 \%$. The optimized SSF conditions were as follows: substrate particle size $0.8-1 \mathrm{~mm}$, initial moisture content $50 \%$, and temperature $30{ }^{\circ} \mathrm{C}$. The optimum compositions of the supplementary glucose and $\mathrm{NaNO}_{3}$ were 1.65 and $0.43 \%(\mathrm{w} / \mathrm{w})$, respectively (Cai et al. 2010). The samples were removed at regular intervals of $48 \mathrm{~h}$ after agitation and were analyzed for different parameters. Fermented substrate was dried at $60{ }^{\circ} \mathrm{C}$ and pulverized to pass through a $0.2-\mathrm{mm}$ sieve. One gram sample was refluxed with $50 \mathrm{~mL}$ methanol in a water bath at $70{ }^{\circ} \mathrm{C}$ for $2 \mathrm{~h}$. The extract was filtered through $0.45-\mu \mathrm{m}$ membrane filter and diluted to $100 \mathrm{~mL}$. After that, hypocrellins was determined by reverse-phase high-performance liquid chromatography (HPLC) (Cai et al. 2010).

\section{RNA isolation and first strand cDNA synthesis}

RNA was isolated using a Takara RNA Extraction Kit (Takara, Ōtsu, Japan) according to manufacturer's protocol. To eliminate genomic DNA, RNA samples were treated with RNase-free DNase I (Takara). The quantity and quality of the total RNA extracted was determined using a NanoDrop-2000C spectrophotometer (Thermo Scientific, Wilmington, DE, USA) and the integrity was evaluated by analyzing the ratio between rRNA subunits of $18 \mathrm{~S}$ and $28 \mathrm{~S}$ after electrophoresis. The first strand cDNA was synthesized by reverse transcribing $500 \mathrm{ng}$ RNA with $5 \times$ All-In-One RT MasterMix (Applied Biology Materials Inc., Richmond, Canada), and cDNA samples were stored at $-20^{\circ} \mathrm{C}$ (Deng et al. 2016b).

\section{Codon optimization and gene synthesis}

Amino acid sequence of $\mathrm{VHb}$ (GenBank accession no. $A A A 75506)$ and corresponding nucleotide sequence of $v g b$ gene were shown in Additional file 1: Figure S1. After codon optimization, the optimized $v g b$ gene (GenBank accession no. MG735184) was synthesized by GENEWIZ, Inc in Soochow (Jiangsu, China). Alignment between original (GenBank accession no. KM108313.1) and optimized $v g b$ gene sequences was shown in Additional file 1: Figure S1. Alpha-amylase gene amy365-1 was cloned when cDNA sample of Shiraia sp. SUPERH168 was used as template.

\section{Plasmid construction}

A lentiviral expression vector, Pgfppuro, obtained from Applied Biological Materials (ABM) Inc. (Richmond, Canada), was chosen as an expression plasmid in $S$. bambusicola which had been confirmed by Deng et al. (2016a). The vector consists of a U6 promoter, green fluorescent protein gene $g f p$, nucleotide sequence encoding 2A peptide, and gene of the protein resistant to puromycin puro (Fig. 1a). On the basis of Pgfppuro, Phyg expression vector and PhygPgpdA coexpression vector were constructed in this study. The 2A oligopeptide is emerging as a highly effective new tool for the facile coexpression of multiple proteins in a single transformation step, whereby a gene encoding multiple proteins, linked by $2 \mathrm{~A}$ sequences, is transcribed from a single promoter (de Felipe et al. 2006). 2A functions has already been applied to coexpress GFP and Hyg selective markers in S. bambusicola as described by Deng et al. (2016a).

The Phyg expression vector was constructed by the following process. First, the gene hyg of Hyg protein was used to replace the $g f p$ of the Pgfppuro expression plasmid. The Pgfppuro vector was linearized through amplification reaction with VF1 and VR1 primers. The Hyg protein gene hyg was amplified from pUCATPH plasmid with primers hygF and hygR. The amplified hyg with 15-bp nucleotides (the underlined sequences in Table 1) was reverse-complemented with the linearized lentiviral vector. On the basis of the 15-bp reverse-complement nucleotides between linearized lentiviral vector and amplified hyg, the ligation-free cloning kit (ABM Inc.,

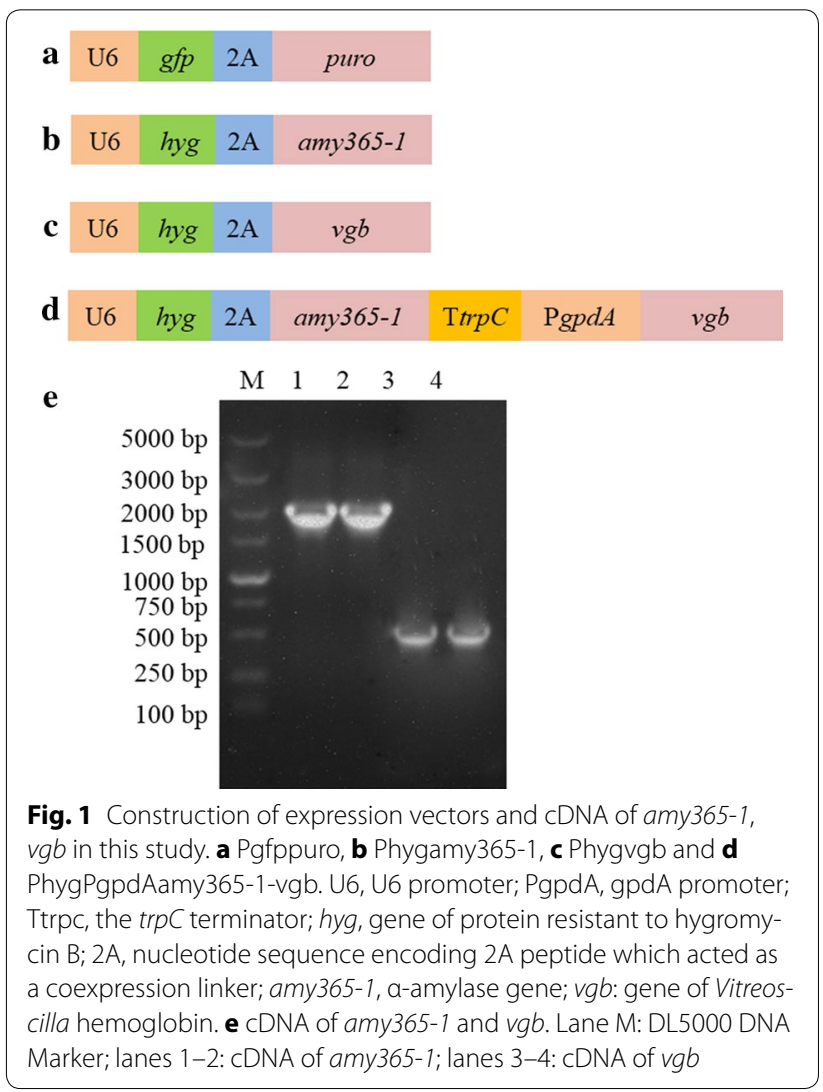


Table 1 Primers used for construction of overexpression plasmid

\begin{tabular}{|c|c|}
\hline Primer symbol & Primers $\left(5^{\prime}-3^{\prime}\right)$ \\
\hline VF1 & GGTGGCACTAGAGAAGACTATTTTTTG \\
\hline VR1 & $\underline{\text { GAATTCGGAAGCGGGCAGTG }}$ \\
\hline hygF & ITCTCTAGTGCCACCATGAAAAAGCCTGAACTCACCG \\
\hline hygR & CCCGCTTCCGAATTCTTCCTTTGCCCTCGGAC \\
\hline VF2 & $\underline{\text { GGATCCGGGGCCGGGGTTGCTC }}$ \\
\hline VR2 & ACGCGTTCCGGAAATCAACCTCTGG \\
\hline amy365-1F & CCCGGCCCCGGATCCATGTCGGCTCCTCGTCCACGAGGC \\
\hline amy365-1R & $\frac{\text { ATTTCCGGAACGCGTTTATTGCCATGTACTATTCACACTC- }}{\text { GAAGCC }}$ \\
\hline $\operatorname{vgbF}$ & $\frac{\text { CCCGGCCCCGGATCCATGCTTGATCAACAAACGAT- }}{\text { CAACA }}$ \\
\hline $\operatorname{vgbR}$ & $\underline{\text { ATTTCCGGAACGCGTCTATTCGACGGCTTGGGCGT }}$ \\
\hline TtrpCF & ATCCACTTAACGTTACTGAAATCATC \\
\hline TtrpCR & CATTTTTCGACAATCCGAGTGGAGATGTGGGAG \\
\hline PgpdAF & GATTGTCGAAAAATGTAAAGG \\
\hline PgpdAR & $\underline{\text { GATGAAGTGTTTGTTGAGCTAGGGGAG }}$ \\
\hline amy365-1R1 & $\frac{\text { TAACGTTAAGTGGATTTATTGCCATGTACTATTCACACTC- }}{\text { GAAGCC }}$ \\
\hline vgbF1 & $\frac{\text { AACAAACACTTCATCATGCTTGATCAACAAACGAT- }}{\text { CAACA }}$ \\
\hline
\end{tabular}

Richmond, Canada) was used to construct Phyg vector by homologous recombination.

In order to overexpress amy365-1, overexpression plasmid Phygamy365-1 (Fig. 1b) was constructed. The gene of PURO protein was replaced by amy365-1. It was constructed in the same way as construction of Phyg vector with linearized plasmid which was amplified with primers VF2 and VR2 and amy365-1 which was amplified with primers amy365-1F and amy365-1R. Phygvgb (Fig. 1c) was also constructed in the same way as Phygamy365-1. $v g b$ was amplified with primers vgbF and vgbR.

In order to coexpress amy365-1 and vgb, coexpression plasmid PhygPgpdAamy365-1-vgb (Fig. 1d) was constructed. It was consisted of the following five fragments (in order): (1) linearized vector amplified from plasmid Phyg with primers VF2 and VR2; (2) amy365-1 was amplified with primers amy365-1F and amy3651R1; (3) the TtrpC terminator amplified from pAN521Not (GeneBank Accession No. Z32524) with primers TtrpCF and TtrpCR; (4) the PgpdA promoter was amplified from genomic DNA of $S$. bambusicola with primers PgpdAF and PgpdAR. PgpdA promoter had been identified and chosen as the native promoter for overexpression in S. bambusicola (Deng et al. 2017). (5) $v g b$ was amplified with primers vgbF1 and vgbR. They were integrated by homologous recombination, and then PhygPgpdAamy365-1-vgb was constructed. All primers used in this study and reverse-complement nucleotides with underlined were showed in Table 1.

\section{Preparation of protoplasts and fungal transformation}

The procedures for fungal protoplast generation and transformation were carried out as described by Deng et al. (2016a). Spore was selected as the original host and the cell wall was eliminated after 4-h degeneration with enzyme mixture. Plasmid $(5 \mu \mathrm{g})$ was added to $200 \mu \mathrm{L}$ of protoplasts in STC solution (1.2 M sorbitol, $10 \mathrm{mM}$ Tris- $\mathrm{HCl}$ and $10 \mathrm{mM} \mathrm{CaCl}_{2}$ at $\left.\mathrm{pH} 7.5\right)$, and $100 \mu \mathrm{L}$ of cold PTC buffer (50\% PEG 3350, $10 \mathrm{mM}$ Tris- $\mathrm{HCl}$ and $10 \mathrm{mM} \mathrm{CaCl}_{2}$ at $\mathrm{pH}$ 7.5) was then added to the mixture. The mixture was incubated on ice for $20 \mathrm{~min}$. Then, $800 \mu \mathrm{L}$ of PTC added to the mixture and kept at room temperature for $15 \mathrm{~min}$, followed by centrifugation at $5000 \mathrm{~g}$ and $4{ }^{\circ} \mathrm{C}$ for $5 \mathrm{~min}$. The supernatant was then discarded. Protoplasts were suspended in regeneration medium and incubated with shaking at $75 \mathrm{rpm}$ and $30^{\circ} \mathrm{C}$ until the cell walls were recovered. Then protoplasts were spread onto the regeneration agar medium with $500 \mu \mathrm{g} /$ $\mathrm{mL}$ of hygromycin $\mathrm{B}$.

\section{Real-time quantitative PCR (RT-qPCR)}

The relative expression levels of hypocrellin biosynthesis genes which included fad, mono, zftf, omef, msf, pks, mco, and related genes in central carbon metabolism which included $p d c$, ald, acs, acc were studied. To standardize the relative quantification of the cDNA, Shiraia sp. SUPER-H168 18S rRNA gene was selected as an endogenous control gene. Primers used for RT-qPCR analysis of hypocrellin biosynthesis genes and related genes in central carbon metabolism were showed in Table 2.

The amplification efficiency (E) of all primer sets was tested with serial dilutions of template cDNA and calculated from the slope of the dilution curve according to the equation:

$$
E=\left[10^{-(1 / \text { slope })}-1\right] \times 100 \% .
$$

The expressions of related genes were assessed in hyphae grown in liquid fermented media. RT-qPCR reactions were carried out in 96-well block with a CFX96 Real-Time PCR Detection System (Bio-Rad, Hercules, CA, USA). The thermal profiles were performed using the following conditions: $95{ }^{\circ} \mathrm{C}$ for $10 \mathrm{~min}, 30$ cycles of $95{ }^{\circ} \mathrm{C}$ for $3 \mathrm{~s}, 57^{\circ} \mathrm{C}$ for $30 \mathrm{~s}, 72{ }^{\circ} \mathrm{C}$ for $30 \mathrm{~s}$. In order to evaluate the specificity of primer sets used for RT-qPCR amplification, the melting curve was analyzed. Every amplification was performed in triplicate.

Relative expression levels of genes were calculated based on the threshold cycle $\left(\mathrm{C}_{\mathrm{T}}\right)$ deviation of the treated sample versus a control and expressed in comparison to 
Table 2 Primers and relevant information of reference and target genes

\begin{tabular}{|c|c|c|}
\hline Gene symbol & Gene name & Primers $\left(5^{\prime}-3^{\prime}\right)$ \\
\hline \multirow[t]{2}{*}{ amy365-1 } & \multirow[t]{2}{*}{ a-amylase } & F:TGGATTACGCTACTTATTAC \\
\hline & & R: GTATTGCTAACGGTATTCA \\
\hline \multirow[t]{2}{*}{$v g b$} & \multirow{2}{*}{$\begin{array}{l}\text { Vireoscilla hemo- } \\
\text { globin }\end{array}$} & F: ATCGTCGGTCAAGAACTT \\
\hline & & R: CCCAGGCATCAAGGATAT \\
\hline \multirow[t]{2}{*}{ fad } & \multirow{2}{*}{$\begin{array}{l}\text { FAD/FMN-containing } \\
\text { dehydrogenase }\end{array}$} & F:TGTGACCGCCATCACCTTAC \\
\hline & & R: TTGTCGTATGGGTGGGAAGC \\
\hline \multirow[t]{2}{*}{ Mono } & \multirow{2}{*}{$\begin{array}{l}\text { Salicylate 1-monoox- } \\
\text { ygenase }\end{array}$} & F:TCTCGGGGAATTATGGCACG \\
\hline & & R: ACAACCGTTCTCGCATCAGT \\
\hline \multirow[t]{2}{*}{ zftf } & \multirow{2}{*}{$\begin{array}{l}\text { Zinc finger transcrip- } \\
\text { tion factor }\end{array}$} & F: GAACACCGTCGCAAGATTCG \\
\hline & & R:TCATTGGCATCGCTTGGAGT \\
\hline \multirow[t]{2}{*}{ omef } & \multirow[t]{2}{*}{ O-methyltransferase } & F: GAACTACCTGAAGGCACGCT \\
\hline & & R: GCTCGGAAGGATACTCGCTC \\
\hline \multirow[t]{2}{*}{ msf } & \multirow{2}{*}{$\begin{array}{l}\text { Major facilitator } \\
\text { superfamily }\end{array}$} & F:TCCCGTAGCCTTGCTTTCTG \\
\hline & & R: CCGGCTTCTTCTTGACGCTA \\
\hline \multirow[t]{2}{*}{ pks } & \multirow[t]{2}{*}{ Polyketide synthase } & F:TGCTGAGGTAGCAGTCAAGC \\
\hline & & R:TTATGCTACGGTCGTCGCTC \\
\hline \multirow[t]{2}{*}{ mco } & \multirow[t]{2}{*}{ Multicopper oxidase } & F:TATGGCGCTACGAGTGGAC \\
\hline & & R: ACTCCCTGGCCGATAACGTA \\
\hline \multirow[t]{2}{*}{ pdc } & \multirow{2}{*}{$\begin{array}{l}\text { Pyruvate decarboxy- } \\
\text { lase }\end{array}$} & F: ATTGTAACGAACTGAATGCT \\
\hline & & R: GTGGTGACTATGGCTGAA \\
\hline \multirow[t]{2}{*}{ ald } & \multirow{2}{*}{$\begin{array}{l}\text { Acetaldehyde dehy- } \\
\text { drogenase }\end{array}$} & F: GTTGGCAGTGAGAATGGA \\
\hline & & R: CTGTTGCGTAGTTGATGATG \\
\hline \multirow[t]{2}{*}{ acs } & \multirow{2}{*}{$\begin{array}{l}\text { Acetyl-CoA syn- } \\
\text { thetase }\end{array}$} & F: GTTGGCTTATACGCTCAA \\
\hline & & R: TTCTGGAATCATAGGTAGGT \\
\hline \multirow[t]{2}{*}{ acc } & \multirow{2}{*}{$\begin{array}{l}\text { Acetyl-CoA carboxy- } \\
\text { lase }\end{array}$} & F: ATCTCAACTGCCGAATACA \\
\hline & & R: AGTGCCAACAATCTCCAA \\
\hline \multirow[t]{2}{*}{185 rRNA } & \multirow[t]{2}{*}{185 rRNA gene } & F: GAAAGTTAGGGGATCGAAGA \\
\hline & & R:TAGTCGGCATAGTTTACGGT \\
\hline
\end{tabular}

reference gene. In this study, wild type strain was selected as a control. Since wild type had no vgb, $\mathrm{C}_{\mathrm{T}}$ of vgb in wild type was set as 30

Relative expression ratio $=2^{[\Delta C T(\text { control })-\Delta C T \text { (treated })]}$.

\section{Residual sugar analysis}

Residual sugar analysis was performed by the amyloglucosidase/ $\alpha$-amylase method (AOAC method 996.11) with the total starch assay kit from Megazyme (Wicklow, Ireland). Under SSF, cracked corn and solid substrates were dried at $80{ }^{\circ} \mathrm{C}$ for $24 \mathrm{~h}$ before analysis (Bluhm and Woloshuk 2005). The residual sugar was also detected under liquid state fermentation.

\section{Results}

In order to increase the use ratio of corn substrate and improve the dissolved oxygen supply, $\alpha$-amylase gene amy365-1 and Vitreoscilla hemoglobin gene vgb were overexpressed, and three plasmids which included
Phygamy365-1, Phygvgb and PhygPgpdAamy365-1-vgb were constructed and three transformants were obtained.

\section{Liquid state fermentation}

Three overexpression vectors were constructed and their transformants were cultured using corn flour as carbon source. Wild type Shiraia sp. SUPER-H168 was chosen as the control strain for analysis of biomass, hypocrellin production, residual sugar and relative expression levels.

Biomass (Fig. 2a) and hypocrellin production (Fig. 2b) were both gradually increased in four strains, at the same time, residual sugar was gradually decreased (Fig. 2c). Three overexpression transformants all had positive effects on biomass and hypocrellin production at different culture times. In addition, hypocrellin production in co-expression strain of AMY365-1 and $\mathrm{VHb}$ reached the highest level $3681 \mathrm{mg} / \mathrm{L}$ at $96 \mathrm{~h}$, it was 5.24-fold compared with wild type strain $(703 \mathrm{mg} / \mathrm{L}$ at $96 \mathrm{~h})$. Hypocrellin productions of two overexpression strains amy365-1 strain and $v g b$ strain reached 2638 and $2362 \mathrm{mg} / \mathrm{L}$ at $96 \mathrm{~h}$, respectively. Biomass and residual sugar in co-expression strain of AMY365-1 and $\mathrm{VHb}$ reached 28.08 and $3.83 \mathrm{~g} / \mathrm{L}$ at $96 \mathrm{~h}$, respectively. While biomass and residual sugar in wild type strain reached 22.89 and $8.35 \mathrm{~g} / \mathrm{L}$ at $96 \mathrm{~h}$, respectively.

\section{RNA validation}

RNA samples isolated from four strains were assessed for integrity and quality. All absorbance ratios at 260/280 nm of RNA samples ranged from 1.8 to 2.0. Agarose gel electrophoresis revealed no degradation.

\section{RT-qPCR analysis of hypocrellin biosynthesis genes and related genes in central carbon metabolism}

In order to analyze the effects of AMY365-1 and $\mathrm{VHb}$ overexpression on genes of hypocrellin biosynthesis, relative expression levels of $\alpha$-amylase gene amy365-1, hemoglobin gene $v g b$, seven hypocrellin biosynthesis genes including fad, mono, zftf, omef, msf, pks, mco and four related genes in central carbon metabolism including $p d c$, ald, acs, acc in three overexpression transformants were studied at 48, 72 and 96 h (Fig. 3). Data of amy365-1 strain (Fig. 3a), vgb strain (Fig. 3b) and coexpression of amy365-1 and $v g b$ strain (Fig. 3c) were shown, respectively.

The relative expression levels of all the studied genes were increased in three overexpression strains compared with the wild type strain, which meant that there was a positive correlation among amy365-1, vgb, hypocrellin biosynthesis genes and related genes in central carbon metabolism. Relative expression levels of seven hypocrellin biosynthesis genes were all increased when AMY365-1 and VHb were overexpressed, especially 

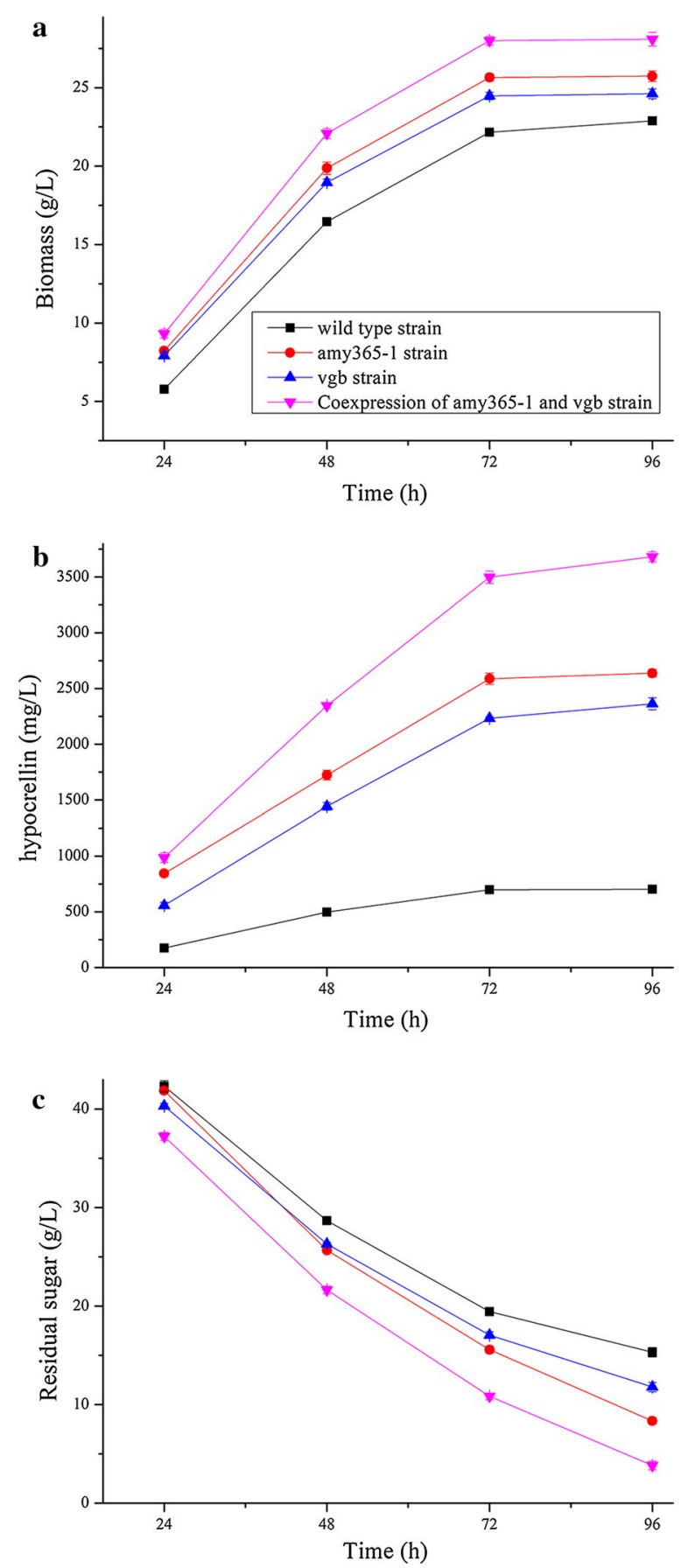

Fig. 2 Biomass (a), hypocrellin production (b) and residual sugar (c) cultured under liquid state fermentation by three overexpression transformants and wild type strain. The error bars represent standard deviation of triplicate measurements. Standard deviations were under 14 per cent of the averages

those of $z f t f$ and $p k s$ were increased clearly in three overexpressed strains. Relative expression levels of $z f t f$ and $p k s$ reached their highest levels in PhygPgpdAamy365-1-vgb
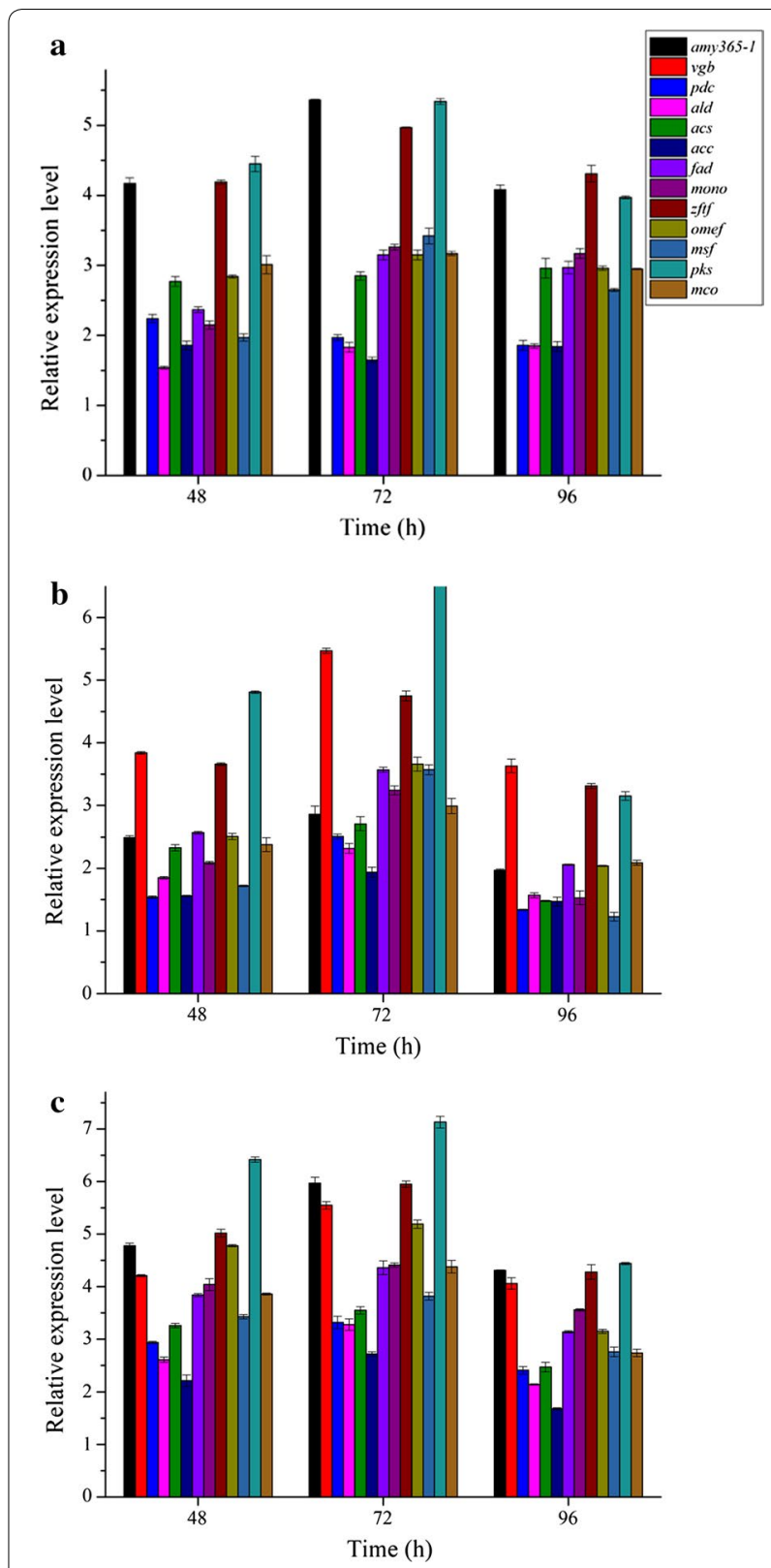

Fig. 3 Relative expression levels of amy365-1, vgb, seven hypocrellin biosynthesis genes and four related genes in central carbon metabolism when cultured on corn flour. a Phygamy365-1, b Phygrgb and c PhygPgpdAamy365-1-vgb. The error bars represent standard deviation of triplicate measurements. Standard deviations were under 7 per cent of the averages

constructed strain at $72 \mathrm{~h}$, they are 5.98 fold and 7.07fold compared with wild type strain, respectively. Relative expression level of amy365-1 was increased when $\mathrm{VHb}$ was overexpressed (Fig. 3b, c). Relative expression level of acs also was increased clearly compared with other $p d h$ and $a c c$ which related to central carbon metabolism in three overexpressed strains. In addition, hypocrellin 
biosynthesis genes reached their highest relative expression levels in PhygPgpdAamy365-1-vgb constructed strain at $72 \mathrm{~h}$. The results agreed with hypocrellin production in liquid state fermentation.

\section{Solid state fermentation}

Hypocrellin productions under SSF were also studied in four strains (Fig. 4). Under SSF, hypocrellin productions were all increased in three overexpression strains compared with wild type strain. In PhygPgpdAamy3651-vgb constructed strain, hypocrellin production reached $75.85 \mathrm{mg} / \mathrm{gds}$ within 11 days which was the highest yield in all studied, and it was 2.99-fold compared with wild type strain $(25.37 \mathrm{mg} / \mathrm{gds})$. Hypocrellin productions in Phygamy365-1 constructed strain and Phygvgb constructed strain reached $64.59 \mathrm{mg} / \mathrm{gds}$ with 13 days and $42.75 \mathrm{mg} / \mathrm{gds}$ with 11 days, respectively. When $\mathrm{VHb}$ was overexpressed, SSF period was reduced to 11 days in Phygvgb constructed strain and PhygPgpdAamy3651 -vgb constructed strain. At $15 \mathrm{~d}$, residual starch of fermented substrates which was cultured by PhygPgpdAamy365-1-vgb constructed strain was $14.57 \%$, compared with that of wild type strain was $35.47 \%$.

\section{Discussion}

Shiraia bambusicola has demonstrated recently its potential for hypocrellin production in fermentation systems and particularly in SSF (Liang et al. 2009). Furthermore, corn was found to be the best substrate after evaluating eight kinds of agro-industrial crops and residues (Cai et al. 2010). Starch is the main constituent in corn, and it also is the main carbon source when hypocrellin was

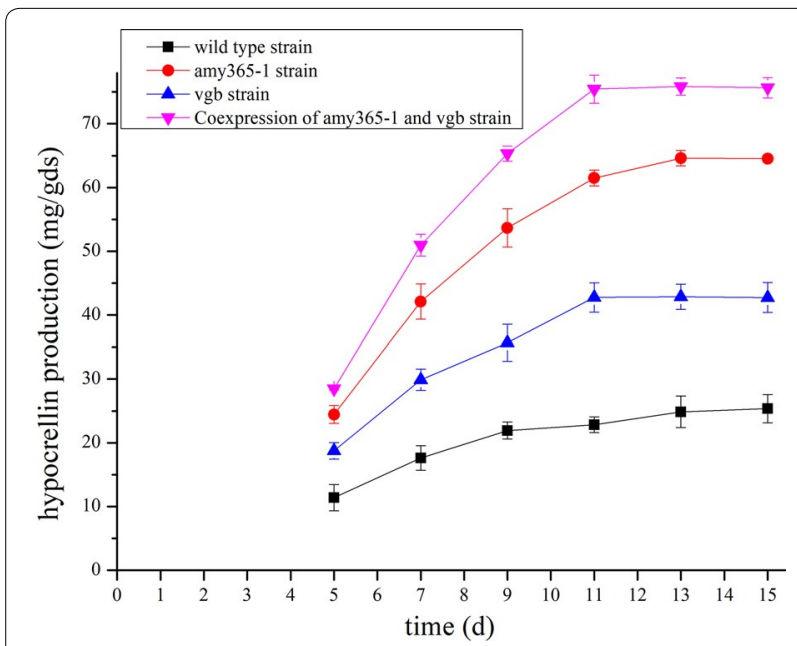

Fig. 4 Hypocrellin production cultured under SSF by three overexpression transformants and wild type strain. The error bars represent standard deviation of triplicate measurements. Standard deviations were under 10 per cent of the averages produced under SSF with S. bambusicola. In addition, it is generally assumed that there is a limitation in the oxygen supply to the cells that are in close contact with the substrate in solid-state cultures with filamentous fungi (Oostra et al. 2001; Rahardjo et al. 2005). The use ratio of corn substrate and oxygen supply were two key aspects which influenced the yield of hypocrellin under SSF. In order to produce hypocrellin at an industrial scale in the future, specific $\alpha$-amylase AMY365-1 and VHb were selected and overexpressed in Shiraia sp. SUPER-H168. Three transformants included Phygamy365-1 strain, Phygvgb strain and PhygPgpdAamy365-1-vgb strain were constructed.

This study showed that $S$. bambusicola harboring amy365-1 yielded higher amounts of biomass and hypocrellin in comparison to wild type strain. The overexpression and function of AMY365-1 result in more efficient hydrolysis of corn starch. Presumably, hypocrellin production was largely dependent on starch catabolism, which accelerate carbon metabolism and ensure the timely and effective supply of glucose in cell. Glycolysis is a central pathway for the catabolism of carbohydrates which converts glucose to two pyruvate molecules. The pathway from pyruvate to acetyl-CoA and malonyl-CoA may be enhanced because relative expression levels of $p d c$, ald, acs and acc were increased when amy365-1 was overexpressed. With respect to hypocrellin biosynthesis genes, relative expression levels of $z \mathrm{ftf}$ and $p k s$ were both increased when amy365-1 was overexpressed. ZFTF is a global transcription factor that mediated gene cluster of secondary metabolite (Yin and Keller 2011), hypocrellin production was increased along with the relative expression level of $z f t f$ increased. PKS (Deng et al. 2016a) was a key enzyme that catalyzed hypocrellin biosynthesized via repetitive decarboxylative claisen condensation of acetylCoA and malonyl-CoA. The relative expression level of $p k s$ was also increased along with that of $z f t$, and this is the main reason why hypocrellin increased.

Furthermore, this study also showed that S. bambusicola harboring $v g b$ yielded higher amounts of biomass, amylase, and hypocrellin in comparison to those of wild type strain. The effects of amy365-1 overexpression and $v g b$ expression and the combination of the two on expression of amy365-1 gene are not simple additive. Maybe it was due to the facts that AMY365-1 was an inducible amylase and relative expression level of amy365-1 was increased when $\mathrm{VHb}$ was overexpressed. The results are in good agreement with previous reports of fungi, where increased levels of biomass and metabolite yields were associated with heterologous expression of $\mathrm{VHb}$. For instance, threefold elevated levels of $\alpha$-amylase and a 31\% increase in the total secreted protein by $\mathrm{VHb}$-expressing Schwanniomyces occidentalis under oxygen-limiting 
environment (Suthar and Chattoo 2006), increased biomass, glucose uptake rate, glycerol production rate, specific oxygen uptake rate and $\mathrm{CO}_{2}$ production rate by Aspergillus niger (Hofmann et al. 2009), improved biomass and protein production by Aspergillus sojae (Mora-Lugo et al. 2015), increased biomass and arachidonic acid production by Mortierella alpine (Zhang et al. 2017), these results were all obtained when engineering these filamentous fungi with $\mathrm{VHb}$. The presence of $\mathrm{VHb}$ did not significantly affect cell growth in Ganoderma lucidum (Li et al. 2016b) and Pseudomonas aeruginosa (Geckil et al. 2001). The results suggest that the function of $\mathrm{VHb}$ may vary in different organisms and under different growth conditions. The biosynthesis of hypocrellin is an energy-requiring process. Energy efficiency is the major constraint for the improvement of hypocrellin production, because ATP is needed during central carbon metabolism and conversion from acetyl-CoA to malonyl$\mathrm{CoA}$. The present and function of VHb in S. bambusicola may result in more efficient energy production, which in turn may have positively effects on central carbon metabolism and hypocrellin biosynthesis.

Relative expression levels of genes which involved central carbon metabolism ( $p d c$, ald, acs, acc) and hypocrellin biosynthesis (fad, mono, zftf, omef, msf, pks, mco) were all increased in three transformants compared with wild type strain. The results in $v g b$ strain are in good agreement with previous reports which showed that presence of $\mathrm{VHb}$ may regulate the expression of host genes (Stark et al. 2015). For instance, the transcription levels of genes $p g m, u g p$, and $g l s$ in the polysaccharide biosynthesis were enhanced in $v g b$-bearing Ganoderma lucidum ( $\mathrm{Li}$ et al. 2016b). The transcriptional levels of the key genes in the electron transfer chain, TCA cycle and welan gum synthesis pathway were enhanced in $v g b$-bearing Sphingomonas sp. HT-1 (Liu et al. 2017). In this study, expressions of AMY365-1 and VHb both increase the activity of transcription factor ZFTF which is a global transcription factor that mediated gene cluster of secondary metabolite.

In other fungi, Cercospora nicotianae which produced cercosporin and Fusarium verticillioides which produced fumonisin $B_{1}$ were both have a zinc finger transcription factor in their polyketide biosynthetic gene cluster. Hypocrellin and cercosporin are all polyketide with polyketomethylene backbone. The core gene cluster for cercosporin biosynthesis includes genes encoding a polyketide synthase, two $O$-methyltransferases, monooxygenase, an MFS transporter, three oxidoreductases and a $\mathrm{Zn}(\mathrm{II})_{2} \mathrm{Cys}_{6}$ transcription regulator (CTB8). CTB8 transcriptional activator controls cercosporin production by controlling gene transcript levels. (Chen et al. 2007).
Additionally, FUM21, which encodes a $\mathrm{Zn}(\mathrm{II})_{2} \mathrm{Cys}_{6}$ transcription factor, is present in the FUM gene cluster, and is required for the transcriptional activation of FUM genes and fumonisin biosynthesis (Brown et al. 2007; Visentin et al. 2012). Among fungi, members of the Cys-2 His-2 $(\mathrm{C} 2 \mathrm{H} 2) \mathrm{TF}$ family are predicted to regulate pathogenicity, cell differentiation, carbon utilization, and development (Park et al. 2008). Carbon availability is a key environmental factor regulating $\mathrm{FB}_{1}$ biosynthesis in $F$. verticillioides. Regardless, signal transduction pathways regulating $\mathrm{FB}_{1}$ biosynthesis in response to carbon metabolites are not completely understood (Kim et al. 2011). In this study, expressions of AMY365-1 and VHb both increase the activity of transcription factor ZFTF. Signal transduction pathways regulating ZFTF in response to carbon and oxygen are not completely understood, and detailed investigations must be performed at molecular level in the future.

Although many encouraging results have been obtained in bacteria, yeast and filamentous fungi, mechanism of $\mathrm{VHb}$ action and regulation should be further elucidated. The presence and function of $\mathrm{VHb}$ in enhancing respiration and formation of ATP has been considered to be the reason for improvements of cell growth, protein synthesis and metabolite production (Stark et al. 2011). Therefore, the $v g b$ gene engineering in Shiraia sp. SUPER-H168 serves as a very effective tool for enhancing growth, respiration, protein synthesis, and metabolism at low exogenous oxygen concentrations especially penetrative hyphae under SSF by promoting oxygen delivery. The mechanism of $\mathrm{VHb}$ on aerobic metabolism has not been fully known. To explain the VHb mechanism in $S$. bambusicola, detailed investigations must be performed at molecular level in the future.

In conclusion, $\alpha$-amylase AMY365-1 and $\mathrm{VHb}$ were both successfully overexpressed and coexpressed in Shiraia sp. SUPER-H168. They both resulted in an improvement of biomass, amylase synthesis, hypocrellin production and up-regulation of relative expression levels of central carbon metabolism genes and hypocrellin biosynthetic genes. At the same time, expression of $\mathrm{VHb}$ resulted in a reduction of SSF period. This study reflects the potentials of $\alpha$-amylase and VHb to enhance hypocrellin production under SSF at an industrial scale in the future.

\section{Additional file}

Additional file 1: Figure S1. Codon optimization of vgb gene. The first line, amino acid sequence of $\mathrm{VHb}$; the second line, original nucleotide sequence of $v g b$ gene; the third line, optimized sequence of $v g b$ gene, changed nucleotides are shown as highlighted with yellow color. 


\begin{abstract}
Abbreviations
ROS: reactive oxygen species; SSF: solid state fermentation; $\mathrm{VHb}$ : Vitreoscilla hemoglobin; fad: FAD/FMN-containing dehydrogenase gene; mono: salicylate 1-monooxygenase gene; zft: zinc finger transcription factor gene; omef: O-methyltransferase gene; msf: major facilitator superfamily gene; $p k s$ : polyketide synthase gene; mco: multicopper oxidase gene; $p d c$ : pyruvate decarboxylase gene; ald: acetaldehyde dehydrogenase gene; acs: acetyl-CoA synthetase gene; acc: acetyl-CoA carboxylase gene; PDA: potato dextrose agar; RT-qPCR: real-time quantitative $P C R$.
\end{abstract}

\section{Authors' contributions}

YC designed the research; RG and HD performed the research and wrote the paper. RG, ZG, YC and XL analyzed the data. All authors read and approved the final manuscript.

\section{Acknowledgements}

We thank the laboratory staff member of Key Laboratory of Industrial Biotechnology, School of Biotechnology, Jiangnan University for all their support.

\section{Competing interests}

The authors declare that they have no competing interests.

\section{Availability of data and materials}

We conducted experiments and data were generated. All data is shown in Figures and Tables within the article.

\section{Consent for publication}

Not applicable.

\section{Ethics approval and consent to participate}

Not applicable. This article does not contain any studies with human participants or animals performed by any of the authors.

\section{Funding}

This work was financially supported by national science foundation of China (Grant No. 21275066), fundamental research of doctor of philosophy at 2014 (Grant No. 2050205), Project of graduate student scientific research and innovation of Jiangsu province at 2015 (Grant No. 205020502), Six talent peak program at 2016 (Grant No. SWYY-126).

\section{Publisher's Note}

Springer Nature remains neutral with regard to jurisdictional claims in published maps and institutional affiliations.

Received: 18 December 2017 Accepted: 16 April 2018 Published online: 02 May 2018

\section{References}

Bluhm BH, Woloshuk CP (2005) Amylopectin induces fumonisin B-1 production by Fusarium verticillioides during colonization of maize kernels. Mol Plant Microbe In 18(12):1333-1339. https://doi.org/10.1094/ mpmi-18-1333

Bonaventura C, Henkens R, Alayash Al, Banerjee S, Crumbliss AL (2013) Molecular controls of the oxygenation and redox reactions of hemoglobin. Antioxid Redox Sign 18(17):2298-2313. https://doi.org/10.1089/ ars.2012.4947

Brown DW, Butchko RAE, Busman M, Proctor RH (2007) The Fusarium verticillioides FUM gene cluster encodes a Zn(II)2Cys6 protein that affects FUM gene expression and fumonisin production. Eukaryot Cell 6(7):12101218. https://doi.org/10.1128/ec.00400-06

Cai YJ, Liang XH, Liao XR, Ding YR, Sun J, Li XH (2010) High-yield hypocrellin A production in solid-state fermentation by Shiraia sp SUPER-H168. Appl Biochem Biotechnol 160(8):2275-2286. https://doi.org/10.1007/ s12010-009-8728-3

Cai YJ, Liao XR, Liang XH, Ding YR, Sun J, Zhang DB (2011) Induction of hypocrellin production by Triton X-100 under submerged fermentation with Shiraia sp SUPER-H168. New Biotechnol 28(6):588-592. https://doi. org/10.1016/j.nbt.2011.02.001

Chen HQ, Lee MH, Daub ME, Chung KR (2007) Molecular analysis of the cercosporin biosynthetic gene cluster in Cercospora nicotianae. Mol Microbiol 64(3):755-770. https://doi.org/10.1111/j.1365-2958.2007.05689.x

de Felipe P, Luke GA, Hughes LE, Gani D, Halpin C, Ryan MD (2006) E unum pluribus: multiple proteins from a self-processing polyprotein. Trends Biotechnol 24(2):68-75. https://doi.org/10.1016/j.tibtech.2005.12.006

Deng HX, Gao RJ, Chen JJ, Liao XR, Cai YJ (2016a) An efficient polyethylene glycol-mediated transformation system of lentiviral vector in Shiraia bambusicola. Process Biochem 51(10):1357-1362. https://doi.org/10.1016/j. procbio.2016.07.013

Deng HX, Gao RJ, Liao XR, Cai YJ (2016b) Reference genes selection and relative expression analysis from Shiraia sp. SUPER-H168 productive of hypocrellin. Gene 580(1):67-72. https://doi.org/10.1016/j.gene.2016.01.019

Deng H, Gao R, Liao X, Cai Y (2017) Genome editing in Shiraia bambusicola using CRISPR-Cas9 system. J Biotechnol. https://doi.org/10.1016/j. jbiotec.2017.06.1204

Fang LZ, Qing C, Shao HJ, Yang YD, Dong ZJ, Wang F, Zhao W, Yang WQ, Liu JK (2006) Hypocrellin D, a cytotoxic fungal pigment from fruiting bodies of the ascomycete Shiraia bambusicola. J Antibiot 59(6):351-354

Gao L, Fei JB, Zhao J, Li H, Cui Y, Li JB (2012) Hypocrellin-loaded gold nanocages with high two-photon efficiency for photothermal/photodynamic cancer therapy in vitro. ACS Nano 6(9):8030-8040. https://doi. org/10.1021/Nn302634m

Geckil H, Stark BC, Webster DA (2001) Cell growth and oxygen uptake of Escherichia coli and Pseudomonas aeruginosa are differently effected by the genetically engineered Vitreoscilla hemoglobin gene. J Biotechnol 85(1):57-66. https://doi.org/10.1016/s0168-1656(00)00384-9

Heerd D, Yegin S, Tari C, Fernandez-Lahore M (2012) Pectinase enzymecomplex production by Aspergillus spp. in solid-state fermentation: a comparative study. Food Bioprod Process 90(2):102-110. https://doi. org/10.1016/j.fbp.2011.08.003

Hofmann G, Diano A, Nielsen J (2009) Recombinant bacterial hemoglobin alters metabolism of Aspergillus niger. Metab Eng 11(1):8-12. https://doi. org/10.1016/j.ymben.2008.07.002

Jin S, Zhou LJ, Gu ZJ, Tian G, Yan L, Ren WL, Yin WY, Liu XD, Zhang X, Hu ZB, Zhao YL (2013) A new near infrared photosensitizing nanoplatform containing blue-emitting up-conversion nanoparticles and hypocrellin A for photodynamic therapy of cancer cells. Nanoscale 5(23):11910-11918. https://doi.org/10.1039/C3nr03515h

Kim H, Smith JE, Ridenour JB, Woloshuk CP, Bluhm BH (2011) HXK1 regulates carbon catabolism, sporulation, fumonisin B-1 production and pathogenesis in Fusarium verticillioides. Microbiol-Sgm 157:2658-2669. https://doi. org/10.1099/mic.0.052506-0

Li HJ, He YL, Zhang DH, Yue TH, Jiang LX, Li N, Xu JW (2016a) Enhancement of ganoderic acid production by constitutively expressing Vitreoscilla hemoglobin gene in Ganoderma lucidum. J Biotechnol 227:35-40. https://doi. org/10.1016/j.jbiotec.2016.04.017

Li HJ, Zhang DH, Yue TH, Jiang LX, Yu XY, Zhao P, Li T, Xu JW (2016b) Improved polysaccharide production in a submerged culture of Ganoderma lucidum by the heterologous expression of Vitreoscilla hemoglobin gene. J Biotechnol 217:132-137. https://doi.org/10.1016/j.jbiotec.2015.11.011

Liang XH, Cai YJ, Liao XR, Wu K, Wang L, Zhang DB, Meng Q (2009) Isolation and identification of a new hypocrellin A-producing strain Shiraia sp SUPER-H168. Microbiol Res 164(1):9-17. https://doi.org/10.1016/j. micres.2008.08.004

Liu XL, Zhu P, Jiang RF, Wu LT, Feng XH, Li S, Xu H (2017) Enhancement of welan gum production in Sphingomonas sp. HT-1 via heterologous expression of Vitreoscilla hemoglobin gene. Carbohyd Polym 156:135142. https://doi.org/10.1016/j.carbpol.2016.08.081

Mora-Lugo R, Madrigal M, Yelemane V, Fernandez-Lahore M (2015) Improved biomass and protein production in solid-state cultures of an Aspergillus sojae strain harboring the Vitreoscilla hemoglobin. Appl Microbiol Biotechnol 99(22):9699-9708. https://doi.org/10.1007/s00253-015-6851-3

Newman AG, Townsend CA (2016) Molecular Characterization of the cercosporin biosynthetic pathway in the fungal plant pathogen Cercospora nicotianae. J Am Chem Soc 138(12):4219-4228. https://doi.org/10.1021/ jacs.6b00633 
Oostra J, le Comte EP, van den Heuvel JC, Tramper J, Rinzema A (2001) Intraparticle oxygen diffusion limitation in solid-state fermentation. Biotechnol Bioeng 75(1):13-24. https://doi.org/10.1002/bit.1159

Park J, Park J, Jang S, Kim S, Kong S, Choi J, Ahn K, Kim J, Lee S, Kim S, Park B, Jung K, Kim S, Kang S, Lee YH (2008) FTFD: an informatics pipeline supporting phylogenomic analysis of fungal transcription factors. Bioinformatics 24(7):1024-1025. https://doi.org/10.1093/bioinformatics/btn058

Rahardjo YSP, Weber FJ, Haemers S, Tramper J, Rinzema A (2005) Aerial mycelia of Aspergillus oryzae accelerate alpha-amylase production in a model solid-state fermentation system. Enzyme Microb Technol 36(7):900-902. https://doi.org/10.1016/j.enzmictec.2005.01.010

Sandhu KS, Singh N (2007) Some properties of corn starches II: physicochemical, gelatinization, retrogradation, pasting and gel textural properties. Food Chem 101(4):1499-1507. https://doi.org/10.1016/j. foodchem.2006.01.060

Shen XY, Zheng DQ, Gao J, Hou CL (2012) Isolation and evaluation of endophytic fungi with antimicrobial ability from Phyllostachys edulis. Bangl J Pharmacol 7(4):249-257. https://doi.org/10.3329/bjp.v7i4.12068

Shi YJ, Xu XQ, Zhu Y (2009) Optimization of Verticillium lecanii spore production in solid-state fermentation on sugarcane bagasse. Appl Microbiol Biotechnol 82(5):921-927. https://doi.org/10.1007/s00253-009-1874-2

Stark BC, Dikshit KL, Pagilla KR (2011) Recent advances in understanding the structure, function, and biotechnological usefulness of the hemoglobin from the bacterium Vitreoscilla. Biotechnol Lett 33(9):1705-1714. https:// doi.org/10.1007/s10529-011-0621-9

Stark BC, Pagilla KR, Dikshit KL (2015) Recent applications of Vitreoscilla hemoglobin technology in bioproduct synthesis and bioremediation. Appl Microbiol Biotechnol 99(4):1627-1636. https://doi.org/10.1007/ s00253-014-6350-y

Su YJ, Rao SQ, Cai YJ, Yang YJ (2010) Preparation and characterization of the inclusion complex of hypocrellin A with hydroxypropyl-beta-cyclodextrin. Eur Food Res Technol 231(5):781-788. https://doi.org/10.1007/ s00217-010-1322-7

Su YJ, Si SH, Qiao LW, Cai YJ, Xu ZM, Yang YJ (2011) The effect of a hypocrellin A enriched diet on egg yolk quality and hypocrellin A distributions in the meat of laying hens. Eur Food Res Technol 232(6):935-940. https://doi. org/10.1007/s00217-011-1461-5
Suthar DH, Chattoo BB (2006) Expression of Vitreoscilla hemoglobin enhances growth and levels of alpha-amylase in Schwanniomyces occidentalis. Appl Microbiol Biotechnol 72(1):94-102. https://doi.org/10.1007/ s00253-005-0237-x

te Biesebeke R, Boussier A, van Biezen N, Braaksma M, van den Hondel CA, de Vos WM, Punt PJ (2006) Expression of Aspergillus hemoglobin domain activities in Aspergillus oryzae grown on solid substrates improves growth rate and enzyme production. Biotechnol J 1(7-8):822-827. https://doi. org/10.1002/biot.200600036

Trachootham D, Lu W, Ogasawara MA, Nilsa RD, Huang P (2008) Redox regulation of cell survival. Antioxid Redox Signal 10(8):1343-1374. https://doi. org/10.1089/ars.2007.1957

Visentin I, Montis V, Doll K, Alabouvette C, Tamietti G, Karlovsky P, Cardinale F (2012) Transcription of genes in the biosynthetic pathway for fumonisin mycotoxins is epigenetically and differentially regulated in the fungal maize pathogen Fusarium verticillioides. Eukaryot Cell 11(3):252-259. https://doi.org/10.1128/EC.05159-11

Wakabayashi S, Matsubara H, Webster DA (1986) Primary sequence of a dimeric bacterial haemoglobin from Vitreoscilla. Nature 322(6078):481483. https://doi.org/10.1038/322481a0

Yin W, Keller NP (2011) Transcriptional regulatory elements in fungal secondary metabolism. J Microbiol 49(3):329-339. https://doi.org/10.1007/ s12275-011-1009-1

Zhang SM, Wang JP, Wei YL, Tang Q, Kanwal M, He J (2014) Heterologous expression of $\mathrm{VHb}$ can improve the yield and quality of biocontrol fungus Paecilomyces lilacinus, during submerged fermentation. J Biotechnol 187:147-153. https://doi.org/10.1016/j.jbiotec.2014.07.438

Zhang HD, Feng YG, Cui Q, Song XJ (2017) Expression of Vitreoscilla hemoglobin enhances production of arachidonic acid and lipids in Mortierella alpina. BMC Biotechnol 17:68. https://doi.org/10.1186/s12896-017-0388-8

Zhu H, Sun SJ, Zhang S (2011) Enhanced production of total flavones and exopolysaccharides via Vitreoscilla hemoglobin biosynthesis in Phellinus igniarius. Bioresour Technol 102(2):1747-1751. https://doi.org/10.1016/j. biortech.2010.08.085

\section{Submit your manuscript to a SpringerOpen ${ }^{\circ}$ journal and benefit from:}

- Convenient online submission

- Rigorous peer review

- Open access: articles freely available online

- High visibility within the field

- Retaining the copyright to your article

Submit your next manuscript at $\boldsymbol{\nabla}$ springeropen.com 